\section{Divergent Approach to Enmein-Type Natural Products}

Gategory

Synthesis of Natural

Products and

Potential Drugs

Key words

Diels-Alder reaction

Birch reduction

reductive alkenylation

ent-kaurenoids<smiles>CO/C=C/C(=O)C(C)C</smiles><smiles>C[13CH][13CH]</smiles><smiles>COc1cccc(I)c1</smiles><smiles>C[13CH3]</smiles>

C

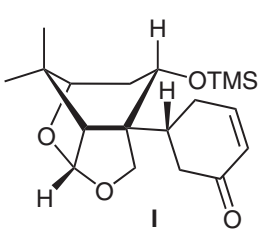
$\mathrm{dr}=4.8: 1$

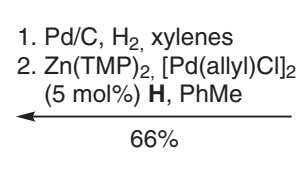
. $\mathrm{Zn}(\mathrm{TMP})_{2}[\mathrm{Pd}$ (allyl)Cl

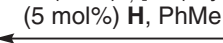

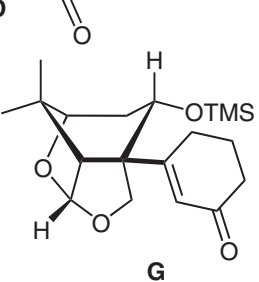

BHT (1 mol\%), PhMe, $100^{\circ} \mathrm{C}$ then $3 \mathrm{M}$ aq HCl, THF

B<smiles>COc1cccc(C2=CC(=O)OC2=O)c1</smiles>
$52 \%$ along with $38 \%$ of epi-E Diels-Alder reaction

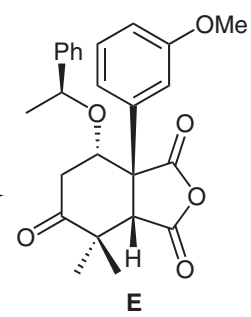

1. $\mathrm{Li} / \mathrm{NH}_{3}$, THF-EtOH (3:1) $-78^{\circ} \mathrm{C}$

2. $3 \mathrm{M} \mathrm{aq} \mathrm{HCl}$

3. $\mathrm{Et}_{3} \mathrm{~N}, \mathrm{TMSCl}, \mathrm{DMAP}$ $\mathrm{CH}_{2} \mathrm{Cl}_{2}, 0^{\circ} \mathrm{C}$ to r.t. $58 \%$ \begin{tabular}{r|r} 
LAH, THF \\
$0-55^{\circ} \mathrm{C} \downarrow$
\end{tabular}<smiles>COc1cccc(C2(c3ccccc3)COC(=O)[C@H]2F)c1</smiles>

$$
\begin{array}{l|l}
\text { LiHMDS, J } & \\
\text { THF, }-78^{\circ} \mathrm{C} & \\
\text { then } \mathrm{NaH} & \\
\mathrm{HMPA}, \mathrm{Nal} & 55 \% \\
\mathbf{K},-78^{\circ} \mathrm{C} \text { to } & \\
\text { r.t., then } 6 \mathrm{M} & \\
\text { aq } \mathrm{HCl} &
\end{array}
$$

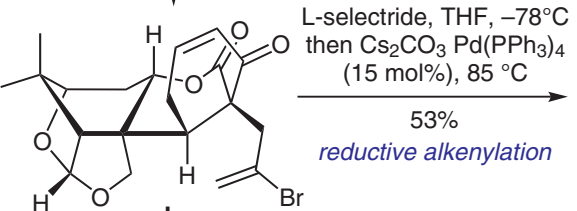

L

9 steps $\downarrow 13 \%$

(-)-Sculponin R

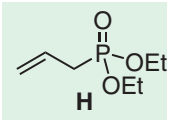

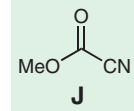

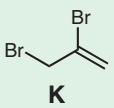

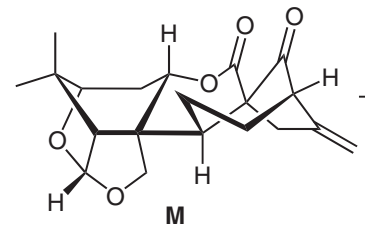

M



(-)-Enmein
7 steps $33 \%$

(-)-Isodocarpin
Significance: Dong and co-workers have attained three highly oxygenated ent-kaurenoids from the isodon family of natural products by means of total synthesis. The significance of the work lies in the expeditious construction of key intermediate $\mathbf{L}$, which was subsequently utilized as a common starting point in the preparation of (-)-sculponin R, (-)-isodocarpin, and (-)-enmein.
Comment: The authors commenced their synthetic route with the assembly of bicyclic ketone $\mathbf{E}$ by Diels-Alder cycloaddition. Birch reduction provided access to acetal $\mathbf{G}$, which was subsequently transformed into enone $\mathbf{I}$. In a single pot, Dong and co-workers constructed pivotal vinyl bromide L. Relying on reductive alkenylation strategies, this pentacycle was used to access the three highlighted natural products.

SYNFACTS Contributors: Erick M. Carreira, Niels Sievertsen

Synfacts 2018, 14(07), 0663 Published online: 18.06.2018 DoI: 10.1055/s-0037-1609866; Reg-No.: C03318SF 